\title{
An Analysis of Metaphysical Conceits in John Donne's Poems
}

\author{
Jiapeng $\mathrm{Du}$ \\ School of Foreign Language, Taishan University, Tai'an, China
}

\begin{abstract}
In the seventeenth century British literary arena appears a unique school of poetry called "metaphysical school". The most remarkable characteristic of the metaphysical poetry is the original and arresting conceits. John Donne is the forefather and the most representative of the school. Through analyzing the sources of conceits in John Donne's poems, this paper attempts to clarify the using of conceits in John Donne's representative poems, and then summarize the features and unique functions of conceits. It is hoped that it can help readers to have a better understanding of the poet's poetry, and grasp his thoughts.
\end{abstract}

Index Terms - metaphysical poetry, John Donne, conceit

In the seventeenth century British literary arena appears a unique school of poetry called "metaphysical school". The word "metaphysics" was first used by the critic and poet, John Dryden. He once criticized John Donne's poems "affects the metaphysics" in his book Discourse Concerning Satire (Jones, 1986, p.55). Later in 1779, Dr. Samuel Johnson extended the word "metaphysical" to the group of poets in early seventeenth century, for example, John Donne, Andrew Marvell, George Herbert and so on. From that time these poets are called metaphysical poets. Metaphysical concerns are a common theme in their poems, exploring the world through rational discussion of world phenomena rather than through intuition or mysticism. The Metaphysical poets were ignored in the 18th and 19th centuries by Romantic and Victorian poets, but there was a new interest among readers and scholars in the 20th century who, from a metaphysical perspective, sought to understand the pressing political and scientific upheavals. In his essay "The Metaphysical Poets", T. S. Eliot, in particular, saw in this group of poets a capacity for "devouring all kinds of experience" (Eliot, 1950, p.241).

John Donne was the most outstanding of the English metaphysical poets, and was also considered a master of the metaphysical conceit. In contrast to the deliberate fluidity and sweetness of tone in much of 16th century poetry, he adopted an energetic, uneven and rigorous style. His work contains a healthy interest in life and its pleasures, while also expressing deep emotion. The using of metaphysical conceits in his poems had an immense influence on the following English poets (Wu, 2013, p.132).

This paper is to concentrate on the study of the outstanding characteristics of metaphysical conceits, and attempts to clarify the using of conceits in John Donne's representative poems, and then summarize the features and unique functions of conceits. It is hoped that it can help readers to have a better understanding of the content of the poet's' poetry, and grasp his thoughts.

\section{AN INTROdUCtion to John DONNE AND METAPHYSICAL CONCEITS}

\section{A. John Donne's Poetic Creation}

John Donne was born in Bread Street, London in 1572 to a prosperous Roman Catholic family - a dangerous thing at that time when anti-Catholic sentiment was common in England. He studied at both Oxford and Cambridge Universities in his early teen years, but got no degree at either university because his catholic belief. His contradiction on religion belief existed in his whole life though he converted to Anglicanism in his twenties. In 1621, he was named dean of St. Paul's cathedral. He attained eminence as a preacher, and "delivering sermons that are regarded as the most brilliant and eloquent of his time" (Sun, 2010, p.46).

At that time, Petrarchan sonnets were popular. The Petrarch sonnet was the first sonnet to be introduced into England. It was first translated into English by Thomas Wyatt in the early 16th century. The sonnet takes its name from the Italian poet, Francesco Petrarch, who lived in Italy in the 14th century. The theme of a typical Petrarchan sonnet is of unattainable love which is seen as one of the purest loves because nothing distracts from it. John Donne tries to break away from the conventional fashion of the sweet, vague and elegant Petrarchan style of writing. His diction is simple and the imagery is drawn, with god or with himself.

John Donne's life was full of ups and downs, and his personal relationship with religion was tumultuous and passionate, and at the center of much of his poetry. Such life experiences provide a wealth of material for his poetry. His works in his early period were very passionate. He wrote a lot of love poems to express his view on love. A good many of The Songs and Sonnets were written in this period. Contrary to the Petrarchan love idea that only spiritual love was praised, Donne holds that the perfection of human lovers will be made with the union of soul and body, and even the body controls the soul. After his marriage, he became more meditative in his works, and his personal religious trials 
still haunted him. He changed his writing theme to religion. And his works were concerning "the decay of the physical universe, the vanity of the world, and in contrast, the permanence of the god and spiritual values" (p.47). Divine Poems and Holy Sonnets were written during this period. In his late time, Donne's works reflected his deep emotions and spirituality. He died in London in 1631 after preaching his own funeral sermon, Death's Duel a few weeks ago.

\section{B. The Concept of Metaphysical Conceits}

Metaphysical conceit is a literary term that refers to a poet's use of somewhat unorthodox language and language construct to describe the quality of an everyday concept (p.48). This literary tool, devised in the 17th century, is often used to describe seemingly intangible concepts like an entity's spiritual and emotional qualities, for example, by using verbose and sometimes paradoxical analogies to objects, like those from the earthly worlds deemed mundane, philosophical, and alchemical in nature. The Petrarchan conceit is another type, and it is out of this conceit, famously used in love poems of the Elizabethan era, that the concept of metaphysical conceit and metaphysical poetry as a genre arose. Its use is seen by some as a dramatic tool by which writers relieved themselves from the established, expected, and orthodox conceptual associations common of the era. Unlike the Petrarchan conceits, which formed clichéd comparisons between more closely related objects (such as a rose and love), Donne's metaphysical conceits go to a greater depth in comparing two completely unlike objects (p.48).

\section{SOURCES OF JOHN DONNE’s CONCEITS}

The two individual events, marriage and convert to the Anglicanism, have a great impact and influence on Donne' life, and his inner conflict, mostly stemmed from these two events. The 17th century was one of the most tempestuous periods in English history. The kings were the open enemy of the people; social unrest, old and new doctrine struggle coexistence, the society was filled with a mood of suspicion disillusionment; on the other hand, the rapid development of natural science, astronomy and navigation which were greatly affected Donne. He had a complex personality and a unique understanding of love, religious, death and all-encompassing universe. He viewed them as exploring objects and the source of creativity, He drew his inspiration from them, and such objects also provided a broad range of materials for his conceits. In this chapter we will explore the metaphysical conceits in John Donne's poems from three aspects as to the sources of conceits.

\section{A. John Donne's Unique Philosophical Reasoning}

Donne's poems are often containing a philosophical analysis and logical reasoning. He tries to illustrate his point of view through the deepest analyzing of a particular question. Take "The Flea" for example. "The Flea" is one of the most typical metaphysical poems of John Donne's. The poem was written in colloquial language with a ridicule tone and surprising conceits, and the reasoning process and conclusions are extraordinary.

In the first two lines, the poet gives us a lot of information: there are two persons in the poem, the listener "you" and the speaker "I", and "I" asked for something but was refused. From the next two lines we know the flea becomes a symbol of "our" combined bodies because our bloods are all in its body. So, the speaker deduces that the little flea combines the two to one and creates a new life. Then the speaker tries to induce the girl: love is a natural requirement like the flea is enjoying by sucking our blood; we should do the same. And that is not a sin or shame. In the first stanza, the image of flea is still in its original look, i.e., a sucking insect. The poet regards "our" blood in its body together as the ecstasy of physical love between lovers. It is the beginning of philosophical argument.

In the second stanza, the girl is about to kill the flea, the speaker hurriedly stops her and explain that there are three lives in the flea, so "three sins in killing three". Then the speaker compares the flea to their "marriage bed" and "marriage temple". In this way, the flea becomes holy. And the speaker wants to use the conceit to express his determination: the combination of bodies is just a form; it will lead us to the highest stage of love, i.e., the realization of marriage and the union of souls.

In the last stanza, from "Cruel and sudden" we know that his advisement is in vain, the girl kills the flea. In the view of the speaker, the killing is equal to the division of the integer which is made up by "you" and "I". Then the speaker blames the girl: what is the guilty of this flea? The girl's response, though we could not hear directly, we can infer from the speaker's words: she is reveled in the happiness by killing the flea, which brings no harm to anyone, and does not feel a little weaker. But this is what the speaker wanted to hear, so he answers immediately: love is as easy as the flea's death, since the flea's death is of no importance, why don't you yield to me? Till now the readers realize that the flea is not just a sucking insect, it is used as an evidence to persuade the girl. The speaker is trying to lure his lover to give up the useless view of virginity and abandon secular ideas, in order to achieve his goals; he uses a seemingly preposterous conceit: he compares the combination of two people to the fusion of blood in the flea. As the flea bites blood, loss of virginity will not affect women's reputation. The seduction is skillful and plausible.

Love poems with flea as image are popular in the seventeenth century in Europe, talking about nothing more but men's envy of fleas which can freely approaching to the body of their girlfriend. On the basis of the traditional mode of metaphor, Donne uses the syllogism argument in his conceit. Indeed, as shown in the "flea", the speaker was not only talking about love, but carrying on a syllogistic reasoning during the conversation, then reached the conclusion. That is, first, the flea sucks our blood, and combines our blood together, so this flea is our "marriage bed" and "marriage 
temple"; then, if you kill this flea, you kill three lives, and commit three crimes; last, since killing this flea does not make you weaker, and then accept my courtship will not reduce your reputation. The using of this conceit is a surprising attempt, which made his argument reasonable.

\section{B. Scientific Experiments and Geographical Discoveries}

Scientific experimental thoughts are another obvious sign of the 17th century literature. People's view of the world experienced unprecedented changes. Heliocentric theory has begun to be widely accepted. The development of navigation and geographical discoveries confirmed the existence of many new places. All these changes have affected people's thinking in many different ways. Donne was willing to know these new ideas and new finds. Supernatural knowledge of the new science sparked his curiosity, and led him to form a variety of conceits. The mark of this era is everywhere in Donne's poetry. Petrarch's metaphors, such as star-like eyes, golden hair and snow skin, which were familiar to people, were hard to be found in Donne's poetry. Instead, scientific terms one after another filled in. Love seems to have nothing to do with science, but Donne has chosen many scientific vocabularies in his love poems. As in the "A Valediction: Forbidding Mourning":

Moving of th' earth brings harms and fears,

Men reckon what it did, and meant,

But trepidation of the spheres,

Though greater far, is innocent.

Dull sublunary lovers' love

-Whose soul is sense- cannot admit

Absence, because it doth remove

The things which elemented it (Donne, 1896, p.51).

In these lines, the poet makes a comparison between earthquake and movement of celestial sphere. Earthquakes often happen in the ground, and could cause harm, so people are frightened. The movement of celestial sphere is the source of earthquake, but it brings no harm to humans. Unlike those former poets, Donne regards the earthquake as the movement of celestial sphere instead of the anger of God. The poet wants to emphasize that the separation of the couple is different from those ordinary people. He views the separation as the movement of celestial sphere, which is holy, mysterious and magnitude, and with no harm to our love.

if they be two, they are two so

As stiff twin compasses are two ;

Thy soul, the fixed foot, makes no show

To move, but doth, if th' other do.

And though it in the centre sit,

Yet, when the other far doth roam,

It leans, and hearkens after it,

And grows erect, as that comes home.

Such wilt thou be to me, who must,

Like th' other foot, obliquely run ;

Thy firmness makes my circle just,

And makes me end where I begun (p.52).

In these lines, Donne makes one of his most famous conceits: the two lovers are likened to the two feet of compass. The conceit contains three meanings: one, the feet of one compass are closely linked, so the real separation was impossible. Two, the feet will reunite at last, so the separation was temporary. Three, the theory of circle. In the poet's view, circle is the symbol of perfection. The starting point is the ending point during the drawing. A compass is used to draw standard circle. And circle stands for perfection and satisfaction, also the symbol of harmony and unity. Donne finds the potential similarities between the compass and couples and with this analogy, poetic metaphors and themes achieve consensus. The perfection lies in the firmness of the fixed foot. Here, the fixed foot symbolizes the faithful of woman. The conceit expresses Donne's thoughtfulness as well as anxiety to his wife. Donne's image of compass comes from Ptolemy's geocentricism, that is, earth is the center of the circle, and the other planet rotates around the Earth. The comparison between the movement of the universe and lover's separation is definitely the result of development of science and the popularization of scientific thoughts.

Take "The Sun Rising" for another example:

Thy beams so reverend, and strong

Why shouldst thou think?

could eclipse and cloud them with a wink,

But that I would not lose her sight so long.

If her eyes have not blinded thine,

Look, and to-morrow late tell me,

whether both th' Indias of spice and mine

Be where thou left'st them, or lie here with me.

Ask for those kings whom thou saw'st yesterday, 
And thou shalt hear, "All here in one bed lay" (p.7).

In this stanza, a conceit is used: the sun is compared to a servant who is neither reverend nor strong. His job is to scout information for the poet. Donne makes this conceit to despise the dignitaries. "I" can deny the sun by a wink, the reason why "I" do not wink is "I" can not lose the sight of my lover. And at last, the poet commands his servant-the sun-to inspect India and all kings whom "you saw yesterday", then reports to his master. In addition, in this section, unfamiliar images are written which show Donne's erudition. Ancient India is famous for the production of spices, and the west indie islands are rich in gold and silver deposits. Eclipse is an astronomical term: the sun will appear eclipse with a wink of an eye. The poet uses his astronomical knowledge to disdain the sun.

She's all states, and all princes I;

Nothing else is;

Princes do but play us; compared to this,

All honour's mimic, all wealth alchemy.

Thou, Sun, art half as happy as we,

In that the world's contracted thus;

Thine age asks ease, and since thy duties be

To warm the world, that's done in warming us.

Shine here to us, and thou art everywhere;

This bed thy center is, these walls thy sphere (p.8).

In this stanza, the poet uses a strange conceit, he compares his lover to "all states" and he himself to "all princes". The poet believes their love is the whole world, and the sun is also being fettered in the couple's house. Here, the sun is still a servant: since warming the world is your duty, warming us is enough.

The poet writes astronomical knowledge in this stanza once again. According to Ptolemy's geocentric theory, since the sun revolves round the earth, this bed, where the two lovers enjoying their sweet love, is the core of the sun's movement, and the walls of the bedroom draw the orbit of the sun. From the description of the sun's movement, it seems that Ptolemy's geocentricism and Copernicus's heliocentricism both affect the poet's thought.

In the poetry of Donne, such conceits are too numerous to mention. They seem strange and donnish at first sight because Donne often seeks images from scientific domain where the ordinary people are not familiar with. Such conceits, on one hand, reflect Donne's dissatisfaction with the conventional fashion of the Elizabethan love poetry, and trying to look for other ways for creation. But more important reason is the needs of fully expressing the theme. Conceits like compasses, the storms and the shock of heaven and earth are influenced by the development of sailing and rise of science. Speaking scientific knowledge in love poems is an innovative attempt both at form and content.

\section{Dualism of the Secularity and Theology}

Donne was born in a Catholic family but was forced to convert to Anglicanism. At his time, the modern science began to develop; the religious believes were shaken, old and new doctrine and faith struggled. The society was filled with a mood of suspicion disillusionment. Donne's poetry was full of description of the relationship between human and the God.

As a special way of thinking, the conceits have become a vehicle to combine the secular and the sacred ideas. Most of Donne's poetry has the dual nature of secular and sacred, it is by means of cross thinking of conceits that Donne is able to express this idea vividly.

The feature is embodied in "The Relic". In this poem, the hero imagines himself lying in his grave. He hopes the gravedigger do not destroy the hair made bracelet. The hero introduces the idea that all the dead will be awakened to revival at the last busy day, which adds a sense of sanctity to the poetry. He might take this opportunity to take back his own soul and the soul of his lover's, and reunite in the tomb.

The poem begins with the secular love: a couple was buried in a grave. In a sense, it is the gravedigger opens the prelude of the story. When the grave is open, a great treasure is showed to the world-a hair made bracelet, which is being regarded as a sacred object later. The disturbing to the dead is like a call for the resurrection at the last day.

After awakening of the soul, the two couples begin to analyze the nature of their love, and find their love is a miracle. Even more important, they finally realize their love is only spiritual, without sex. Their love is as holy as angels. The "holy", here represents both the Catholic and the Puritan's view towards holy love. It sublimates the essence of love.

The hair made bracelet is the evidence of the couple's love; the hero does not think people should pray to him and his lover, because people can only pray to God. In fact, the hero has put him and his lover to the equal status with God, and their bones and the bracelet become holy things later. Donne uses this sacred conceit to praise the hero's noble love.

Donne has never declared how great the hero's love is, and do not make any oath, either. But he is able to explore the hero's love in a rational way, and make it to the extent of worship by the later generation. In this process, the sanctity of metaphor can always be the most powerful means to help convey profound and subtle emotions.

As Donne puts in "The Flea", "This flea is you and I, and this/ Our marriage bed, and marriage temple is". In religious terminology, temple is a sacred and inviolable place designed for the worship, a place to communicate with God. The poet used the religious image to illustrate that the flea was the bridge of our love, should not be killed. "And in this flea our two bloods mingled be. / And pampered swells with one blood made of two, / Oh stay, three lives in one flea spare, / And sacrilege. three sins in killing three"(p.18). The lines above remind us that the St. Panick had explained 
the Trinity (the Father, the Son, and the Holy Spirit) to the crowd with a clover. In the eyes of the common, the Trinity is the supreme, the incomparable God's image, the core of the Christian faith. Destroying the trinity is equal to desecrating the Holy Spirit. The three objects, the bloods of hero and heroine, and a new life brought by the mingling of the bloods, unite in the body of the flea. Is it the Trinity? In this way, a small flea is sublimated as the substitute of God, so the readers are taken to a sacred religious state by the trinity of supreme. The lust of the secular and devout faith connects together. It is Donne that can boldly express such sacred image in a secular way, which is showing the innovation of his poetry.

\section{FEATURES AND FunCTIONS OF DONNE’s CONCEITS}

From the analysis above, we see metaphysical conceits are very common in John Donne's poems, and it is clear to find some unique features of Donne's conceits.

First, defamiliarization. Common image, special emotion. Some images can be found in their poetries, but they are endowed with different emotional colors. Donne's creative contribution lies in the adding of new meaning to the original image, for example, "sun". The image brings light and heat to the earth, and provides energy for the growth of all living things. However, in Donne's poetry, "The Sun Rising", the sun is viewed as a "busy old fool, unruly sun". The same sun has different meaning in the poetry of Elizabeth period. Take Shakespeare's "Sonnets 33: only for the beautiful girl in the world" for example, "full many a glorious morning have I seen, / flatter the mountain tops with sovereign eyes". The mountain stands for "me", and sun is the symbol of love. It's common to compare the love to sun in Renaissance's poetry. Love brings poets hope and joy, just as sun gives all creatures light and heat.

Second, ordinary objects are sublimated, and sacred things are demoted, this is another feature of Donne's conceits. Take love theme for example. Love is a theme to which many poets in all cultures have dedicated their lines. Renaissance is a time marked with humanism and lyrics. The Renaissance lyrics inherit the rules and norms set by the Italian forerunner Petrarch. Petrarch not only sets down the rhyme scheme and rules of structure, but also establishes the common images in love poetry. Love is compared to roses or some divine figure in Renaissance Sonnet. Petrarch's metaphors, such as star-like eyes, golden hair and snow skin, are familiar with people. And love in Renaissance poetry is prevalently expressed in the image of beautiful, pure and abstract things. Love to Renaissance poets is identified with ideal and perfection. Take the image flea for example, fleas look ugly, and suck blood for a living. Such a creature is born to describe something bad, but in "The Flea", the flea becomes a symbol of combined bodies because bloods are all in its body, and Donne compares the little flea to "marriage bed" and "marriage temple". In this way, the flea becomes holy. Also, the flea is regarded as the Trinity, so the little flea becomes the substitute of God. On the contrary, as humanity's most familiar image, the sun is always being praised. In the culture of many peoples, the sun is the supreme and the most respected and worshipped. But in "The Sun Rising", the great sun is demoted to the servant of the poet.

Third, Donne's conceits are not based on the similar appearances, but on the similar functions and feelings. For example, the feet of compass have nothing to do with two lovers in appearance, but the departing of two feet is similar to the departing of lovers, and the action of drawing circle is like the missing between two lovers. And the buried bones are horrific, but they symbolize true love.

Why the poet chooses to use so many metaphysical conceits in his poems, because these conceits have unique functions.

First, the defamiliarization effect. As the typical tool for Donne to express his emotion, conceits are used to defamiliarize the familiar things, which increased difficulties for understanding, so the readers have to take an emotional experience at the same time when comprehending the poem. In this way the aesthetic purpose that poetry as an art can be achieved. Since Sir Thomas Wyatt introduced Petrarchan sonnets to Britain, this kind of poetry is popular. In Donne's time, English poets were deeply influenced by Petrarch's ideas and used them repeatedly in their own poetry. For example, the eyes are compared to the stars or the sun, the hair to the thread of gold, the lips to the cherry, the woman to the goddess, and so on. His oxymorons, like frozen fire or burning ice, are also common. But Donne never compares women to flowers or other beautiful things because he tries to break away the conventions of Patriarch's style of metaphors. Traditional metaphors of love are completely replaced by his metaphysical conceits. The flea became the symbol of love and marriage, and the two feet of a compass are the embodiment of loyalty of the lovers.

Second, cultural transmission effects. The interpretation of Donne's metaphysical conceits is like a cultural travel with the poet. The rich cultural heritage of the whole generation will be presented in front of the readers. While reading Donne's conceits. Readers can get detailed information about the 17th century. For example, when we read "A Valediction: Forbidding Mourning", we can find many strange images connected with popular culture at that time. From the comparison between "earthquake and movement of celestial sphere", we can infer that development of science and the popularization of scientific thoughts.

\section{CONCLUSION}

As a great master in British poetic history and the leader of metaphysical poets, Donne astonishes the world by his novel and profound conceit. His powerful and vigorous, concise and simple language, together with his colloquial and 
straightforward dramatic language effect, injected fresh blood into 17th century's British poets, which sets metaphysical poetry as a vital phase in the process of English poetry's development. His broad knowledge, delicate feelings, fertile imagination and subtle words, distinguish his poems. The poet's character and the contradiction of life forced him to record his struggling inner world in a new way, a way characterized by conceit and contemplation. Love in Donne's poems is not as pure as before, it is a combination of spiritual and body pleasure. And Donne is good at using philosophical analysis and metaphysical conceits to express his point of view. His poems often contain religious imagery, and God is not much divine. Man can share the same status with God in some cases. The abstractness, analyticity, complexity, and contradictoriness of his work make his poets worth reading and deliberating carefully. There is rich culture and a vast space for imagination behind his poems. This paper makes a preliminary analysis, clarifies the using of conceits in John Donne's representative poems, and then summarizes the features and unique functions of conceits. The author believes there will be more and more modern readers fascinated by Donne's enthusiastic and intelligent way of thinking. With its unique charm, John Donne's poetry is beautiful scenery in the English literature, which has an everlasting influence on later generations.

\section{REFERENCES}

[1] Bloom, Harold. (1986). John Donne and the Seventeenth-Century Metaphysical Poets. Ed. New York and Philadelphia: Chelsea House Publisher.

[2] Donne, John. (1896). Poems of John Donne. Vol.I. E. K. Chambers, ed. London: Lawrence \& Bullen.

[3] Eliot, T, S. (1950). The Metaphysical Poets, Selected Essays. New York: Faber and Faber.

[4] Hu Jialuan. (2003). Annotated Classic British Poems. Beijing: Foreign Language Teaching and Research Press.

[5] Jones, R. T. (1986). Studying Poetry: An Introduction. London: Edward Arnold Publishers LTD.

[6] Keynes, Geoffrey. (1973). A Bibliography of Dr. John Donne. Oxford: Clarendon Press.

[7] Sun Huaxiang. (2010). Highlights of British Literature. Beijing: China Social Sciences Press.

[8] Williamson, George. (1967). A Reader's Guide to The Metaphysical Poets. London: Thames and Hudson.

[9] Wu Di. (2013). A Study of Metaphysical Poetry. Beijing: China Social Sciences Press.

[10] Yang Zhouhan. (1985). Seventeenth Century English Literature. Beijing: Peking UP.

Jiapeng Du is an English teacher and lecturer at Taishan University. His research interests are mainly British and American literature, comparative literature and English teaching. 